\title{
Dynamical downscaling of temperature variability over Tunisia: evaluation a 21-year-long simulation performed with the WRF model
}

Bilel Fathalli ${ }^{1^{*}}$, Benjamin Pohl ${ }^{2}$, Thierry Castel ${ }^{2}$ and Mohamed Jomâa Safi ${ }^{1}$

${ }^{1}$ Université de Tunis El Manar, Ecole Nationale d'Ingénieurs de Tunis, Tunis, Tunisie

${ }^{2}$ Centre de Recherches de Climatologie, Biogéosciences, CNRS / université de Bourgogne Franche-Comté, Dijon, France

*Corresponding author: BileIFathalli, Université de Tunis El Manar, Ecole Nationale d'Ingénieurs de Tunis, Tunisie, E-mail: bilelfathalli@yahoo.fr

Received date: May 10, 2016; Accepted date: May 18, 2016; Published date: May 26, 2016

Copyright: ( 2016 Fathalli B, et al. This is an open-access article distributed under the terms of the Creative Commons Attribution License, which permits unrestricted use, distribution, and reproduction in any medium, provided the original author and source are credited.

\begin{abstract}
This study evaluates the capabilities of the Weather Research and Forecasting (WRF) model to reproduce the space-time variability of near-surface air temperature over Tunisia. Downscaling is based on two nested domains with a first domain covering the Mediterranean Basin and forced by 21 years of ERA-Interim reanalysis (1991-2011), and a second domain (12 km spatial resolution) centered on Tunisia. Analyses and comparisons are focused on daily average $\left(T_{\text {avg }}\right)$, minimum $\left(T_{\min }\right)$ and maximum $\left(T_{\max }\right)$ near-surface air temperatures and are carried out at the annual and seasonal timescales. WRF results are assessed against various climatological products (ERA-Interim, EOBS and a local network of 18 surface weather stations).

The model correctly reproduces the spatial patterns of temperature being significantly superimposed with local topographic features. However, it broadly tends to underestimate temperatures especially in winter. Temporal variability of temperature is also properly reproduced by the model although systematic cold biases mostly concerning $T_{\max }$, reproduced throughout the whole simulation period, and prevailing during the winter months. Comparisons also suggest that the WRF errors are not rooted in the driving model but could be probably linked to deficiencies in the model parameterizations of diurnal/nocturnal physical processes that largely impact $T_{\max } / T_{\min }$.
\end{abstract}

Keywords: WRF; Near-surface air temperature; Tunisia; Downscaling

\section{Introduction}

Downscaling is a regionalization approach for obtaining highresolution climate or climate change informations from relatively coarse resolution global models [1]. This strategy allows to account for more realistic surface features (such as topography, land-use complexity and heterogeneity) and small scale atmospheric processes (e.g., convective systems) which are not properly represented or resolved by General Circulation Models (GCMs) owing to their coarse resolution (typically run at $150-300 \mathrm{~km} \mathrm{[2]).}$

This is of primary importance for decision makers demanding climate informations at fine spatial scales (about 10-50 km) in order to address climate change risks and potential impacts, and subsequently to implement adaptive measures to reduce or to avoid these risks $[3,4]$. Two widely used downscaling techniques can derive climate informations initially provided by GCMs at the needed regional or local scales $[5,6]$. While statistical downscaling techniques establish statistical relationships between variables at different spatial scales [7], the dynamical downscaling approach avoids relying on empirical observed relationships [8] and is based on coupling large scale climate dynamics and local climate and hydrological futures by using regional climate models (RCMs) [2].

As they use finer surface parameters and more elaborated physical parametrization schemes, RCMs can potentially improve the simulation ability for regional climates over various regions of the world and thus their use has been steadily increased over the last decades. In this paper, we aim at evaluating the capability of a nonhydrostatic limited area model, namely the Weather Research and Forecasting (WRF) model, to dynamically downscale near-surface air temperature (temperature at $2 \mathrm{~m}$ ) over Tunisia. WRF has been largely used by the scientific community and showed good skills in reproducing climate variability [9-12], justifying its use as an RCM in this study.

The need to examine the Tunisian present space-time variability of surface temperature at high-resolution (about $12 \mathrm{~km}$ ) is motivated by the complex geomorphology of Tunisia with high mountains in the north, land depressions in the west central and desert in the south implying large climate gradients, and also by the extreme vulnerability of Tunisia to climate change given its location within the Mediterranean Basin (considered as one the "Hotspots" projected to encounter major climatic changes in the twenty-first century as a result of the global warming).

Lying in a contact zone marking the transition between the temperate humid Mediterranean climate and the dry Saharan climate, the Tunisian climate varies from extremely arid in the south with extreme warm temperatures, significant interannual variability in rainfall and severe drought episodes to a Mediterranean climate in the north. Meteorological records, derived climate indices and satellite products show that the Tunisian climate is getting hotter, drier and more variable. For instance, average temperature rose by about $1.4^{\circ} \mathrm{C}$ in the twentieth with the most rapid warming rate since the 1970's, particularly in summer. The northern and southern regions are experiencing the greatest warming rates [13].

High resolution data provided by RCMs is then strongly needed to help understand the current Tunisian climate variability and its 
impacts on specific sectors (e.g., agriculture, water resources, disease incidence, etc.).

In this study, we focus on the near-surface air temperature regarding its essential role in controlling large variety of environmental processes involved in the water, matter and energy cycles [14]. The main futures of the near-surface temperature space-time variability are described as well as the model skills and errors.

\section{Data and methods}

\section{Data}

To assess the performance of the regional model to downscale nearsurface air temperature variability over Tunisia, we first compare WRF to its driving model. The European Centre for Medium-Range Weather Forecasts (ECMWF) ERA-Interim [15] (ERA-I, hereafter) reanalysis is used to force the WRF model and also to evaluate the WRF-simulated temperature. ERA-I covers the period from 1979 onwards. Its data assimilation and modeling system is based on the Integrated Forecast System (IFS Cy31r2) model. This system includes a 4-dimensional variational analysis (4D-Var) with a 12-hour analysis window. ERA-I spatial resolution is approximately $80 \mathrm{~km}$ (T255 spectral truncation) on 60 vertical levels from the surface up to $0.1 \mathrm{hPa}$.

The other used gridded product is the European (ECA\&D) landonly E-OBS daily gridded dataset [16], provided by the European Climate Assessment and Dataset project (ECA\&D) and covers the period 1950 to present. E-OBS has been developed as part of the ENSEMBLES European project and is based on daily observations from a gradually expanding network of over 3500 stations [17] interpolated onto a regular grid using thin-plate splines and kriging [16]. ERA-I and E-OBS are linearly interpolated onto WRF grid for direct comparison purposes.

Simulated surface temperature is also compared to local surface observations of daily average temperature belonging to the Tunisian National Institute of Meteorology and obtained from NOAA's National Climatic Data Center (NCDC). Available observations were checked for continuity, retaining only 18 stations for model validation by using the nearest grid point of the model to the observation. The low density of surface stations does not permit in fact interpolation of the data to a regular grid.

\section{Methods}

The model used in this work is the Weather Research and Forecasting/Advanced Research WRF (ARW) model [18] in its version 3.3.1 (WRF hereafter). WRF is a next-generation limited area, fully compressible, non hydrostatic with terrain following eta coordinate mesoscale modeling system. It has a rapidly growing user community and has been designed to serve both operational forecasting and climate research purposes. Our WRF simulation was setup with two domains, one at $60 \mathrm{~km}$ and a second at $12 \mathrm{~km}$ horizontal grid spacing, using the two-way nesting technique. The coarse (or parent) domain (120 x 60 grid points) extends over the Mediterranean Basin (Southern Europe and North Africa) while the high-resolution nest (46 x 71 grid points) covers the most part of Tunisia (Figure 1).

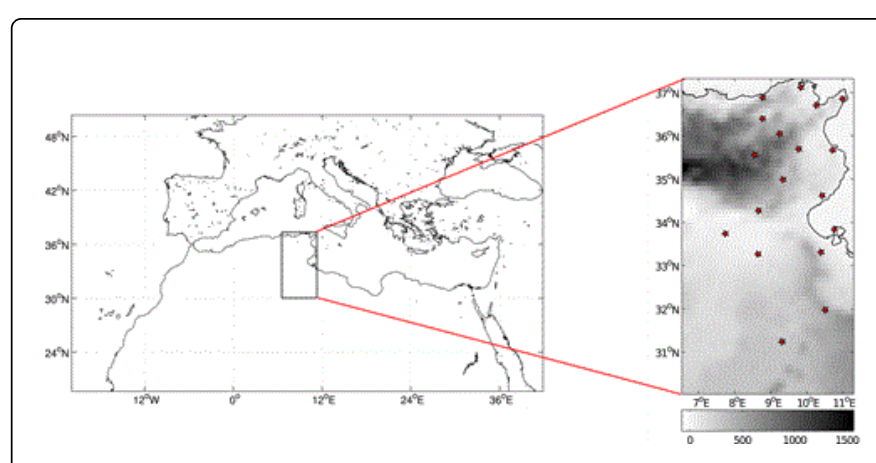

Figure 1: Presentation of the WRF domains. Shadings represent the topography of Tunisia at $12 \mathrm{~km}$ resolution such as it appears in WRF. Geographic positions of the Tunisian weather stations are located within the domain.

Both domains have 28 vertical levels between the surface and 50 $\mathrm{hPa}$. The initial and lateral boundary conditions for the parent domain are provided by ERA-I. Lateral forcings are provided every $6 \mathrm{~h}$ at a $0.75^{\circ}$ horizontal resolution and 19 pressure levels. A buffer zone composed of five grid points (1-point specified zone and 4-point relaxation zone) on the periphery of the domain is chosen and allows for a smooth transition between the model's prognostic variables and the driving reanalysis. Sea Surface Temperature (SST) fields are prescribed every $24 \mathrm{~h}$ by linear interpolation of monthly ERA-I SST.

The physical parameterizations chosen for the two domains include the WRF Single Moment 6-class (WSM6 [19]) cloud microphysics, the Yonsei University parameterization of the Planetary Boundary Layer (PBL, [20]), the MM5 similarity surface layer scheme [21], the Rapid Radiative Transfer Model (RRTP) scheme [22] for longwave and the Dudhia scheme for shortwave radiation [23]. The Kain-Fritschscheme [24] is used to parameterize atmospheric convection. Over the continent, WRF is coupled with Noah LSM 4-layer soil temperature, soil and canopy moistures model [25]. Surface data is derived from the 20-category Moderate Resolution Imaging Spectroradiometer (MODIS) land use data with inland water bodies [26].

The WRF run started at 0000 UTC 1 January 1991 and ended at 2400 UTC 31 December 2011, with the first year being discarded for spin-up. Temperature is archived each hour.

Analyses and comparisons are focused on daily average, minimum and maximum near-surface air temperatures (respectively $\mathrm{T}_{\mathrm{avg}}, \mathrm{T}_{\min }$ and $\left.\mathrm{T}_{\max }\right)$ and are carried out at the annual and seasonal. Different verification metrics (Mean Error (ME), Root Mean Square (RMSE) and Pearson correlation coefficient (R)) are used to evaluate the WRF simulation. They are defined as:

$$
\begin{aligned}
& M E=\frac{1}{N} \sum_{i=1}^{N}\left(S_{i}-O_{i}\right) \\
& R M S E=\sqrt{\frac{1}{N} \sum_{i=1}^{N}\left(S_{i}-O_{i}\right)^{2}} \\
& R=\frac{\sum\left(S_{i}-\bar{S}\right) \cdot(O i-\bar{O})}{\sqrt{\sum\left(S_{i}-\bar{S}\right)^{2} \cdot \sum\left(O_{i}-\bar{O}\right)^{2}}}
\end{aligned}
$$

(S: simulated Temperature, O: observed temperature and N: number of grid-points) 
Citation: Fathalli B, Pohl B, Castel T, Safi MJ (2016) Dynamical downscaling of temperature variability over Tunisia: evaluation a 21-year-long simulation performed with the WRF model. J Climatol Weather Forecasting 4: 166. doi:10.4172/2332-2594.1000166

Page 3 of 8

ERA-I is however compared to the same references (E-OBS and TN_OBS) in order to know if WRF outperforms or not its driving model (i.e. whether the model improves or not the ERA-I driving temperature). Error measures are computed for common WRF, ERA-I and E-OBS landmasses (i.e after applying a mask to exclude WRF and ERA-I grid points within the Mediterranean Sea), or for the nearest grid points of gridded datasets to the Tunisian weather stations.

To better understand temperature variability and also the WRF biases, we separately examine the daily maximum and minimum nearsurface temperatures $\left(\mathrm{T}_{\max }\right.$ and $\mathrm{T}_{\min }$ ). The simulated $\mathrm{T}_{\min }$ and $\mathrm{T}_{\max }$ obtained from the WRF hourly temperature output are then compared to the same gridded datasets.

\section{Results and discussion}

\section{Spatial variability of temperature}

Daily average temperature (Tavg): Long-term (1992-2011) climatologies of annual mean $\mathrm{T}_{\mathrm{avg}}$ simulated by WRF and derived from ERA-I and E-OBS are computed on the basis of the annual means and are shown in Figure 2a. Overall, the spatial distribution of $\mathrm{T}_{\text {avg }}$ is heterogeneous, significantly superimposed with local orographic features and showing a clear altitudinal gradient.

Indeed, the minimum simulated $\left(\sim 12^{\circ} \mathrm{C}\right)$ and observed $\left(\sim 14^{\circ} \mathrm{C}\right.$ according to E-OBS) $\mathrm{T}_{\text {avg }}$ are observed along the main Tunisian mountain ranges, particularly along the Tunisian Dorsale (a southwestnortheast trending mountain range that mostly constitutes the eastern end of the Atlas Mountain and runs across Tunisia from the Algerian border in the west to the Cap Bon Peninsula in the east) and secondarily along the low sandstone Dahar mountain chain bisecting the south of Tunisia. Maximum simulated $\mathrm{T}_{\mathrm{avg}}\left(\sim 23^{\circ} \mathrm{C}\right)$ occurs in the west central of Tunisia particularly in the Tunisian salt depressions (the Chotts region), and south of the country on the margins of the Sahara
(Grand Erg Oriental) and is in good agreement with the comparing datasets.

Figure $2 \mathrm{~b}$ shows the spatial distribution of the 20-year average annual $\mathrm{T}_{\text {avg }}$ biases. Near-surface temperature is slightly overestimated by WRF over the north of the country. Nonetheless, the model underestimates temperature mainly along the aforementioned Tunisian mountain ranges where the cold bias can reach $\sim-4^{\circ} \mathrm{C}$ eventually denoting strong orographic forcing, and less intensively elsewhere. Similar findings are reported by [11] for the North Western Mediterranean Basin where WRF (driven by ERA-40) particularly underestimates surface temperature along the Pyrenees. When compared to E-OBS, ERA-I slightly overestimates/underestimates air temperature in the center of Tunisia/south of the Tunisian Dorsale. Mean annual errors are summarized in Table 1.

Pearson's correlation coefficients quantifying the spatial matching between WRF and the comparing datasets are also listed in same table. Results show that ERA-I roughly performs better than WRF as indicated by the lower values of ME and RMSE. This result is somewhat expected since various surface observations are assimilated within the ERA-I reanalysis system. The high correlation coefficients between WRF and the other datasets (e.g., $\mathrm{R}=0.97$ with regard to $\mathrm{E}$ OBS) denote the good ability of the model in correctly reproducing temperature spatial variability.

Spatial distributions of seasonal mean $\mathrm{T}_{\text {avg }}$ climatologies from WRF, ERA-I and E-OBS are displayed in Figure 3. Seasons are defined as winter [December-January-February (DJF)], spring (MAM), summer (JJA), and autumn (SON). The atitudinal temperature gradient prevails throughout the year. Minimum simulated $\mathrm{T}_{\text {avg }}\left(\sim 3^{\circ} \mathrm{C}\right)$ is in fact recorded in DJF over the Tunisian Dorsale, while the maximum ( $34^{\circ} \mathrm{C}$ ) is registered in JJA over the land depression of "Chott elGharsa" which constitutes the lowest altitudes of Tunisia $(\sim-17 \mathrm{~m})$.

\begin{tabular}{|c|c|c|c|c|c|c|c|c|c|c|c|c|c|c|c|c|}
\hline \multirow[b]{2}{*}{ Model } & \multirow[b]{2}{*}{ Ref } & \multicolumn{3}{|c|}{ Annual } & \multicolumn{3}{|l|}{ DJF } & \multicolumn{3}{|l|}{ MAM } & \multicolumn{3}{|l|}{ JJA } & \multicolumn{3}{|l|}{ SON } \\
\hline & & $\begin{array}{l}\mathrm{ME} \\
\left({ }^{\circ} \mathrm{C}\right)\end{array}$ & $\begin{array}{l}\text { RMSE } \\
\left({ }^{\circ} \mathrm{C}\right)\end{array}$ & $\mathrm{R}$ & $\begin{array}{l}\mathrm{ME} \\
\left({ }^{\circ} \mathrm{C}\right)\end{array}$ & $\begin{array}{l}\text { RMSE } \\
\left({ }^{\circ} \mathrm{C}\right)\end{array}$ & $\mathrm{R}$ & $\begin{array}{l}\mathrm{ME} \\
\left({ }^{\circ} \mathrm{C}\right)\end{array}$ & $\begin{array}{l}\text { RMSE } \\
\left({ }^{\circ} \mathrm{C}\right)\end{array}$ & $\mathrm{R}$ & $\begin{array}{l}\mathrm{ME} \\
\left({ }^{\circ} \mathrm{C}\right)\end{array}$ & $\begin{array}{l}\text { RMSE } \\
\left({ }^{\circ} \mathrm{C}\right)\end{array}$ & $\mathrm{R}$ & $\begin{array}{l}\mathrm{ME} \\
\left({ }^{\circ} \mathrm{C}\right)\end{array}$ & $\begin{array}{l}\text { RMSE } \\
\left({ }^{\circ} \mathrm{C}\right)\end{array}$ & $R$ \\
\hline \multirow{4}{*}{ WRF } & ERA-I & -1.02 & 1.28 & 0.95 & -1.46 & 1.62 & 0.91 & -0.97 & 1.2 & 0.97 & -0.83 & 1.37 & 0.94 & -1.08 & 1.32 & 0.93 \\
\hline & E-OBS & -1.12 & 1.28 & 0.97 & -2.15 & 2.36 & 0.84 & -0.93 & 1.08 & 0.98 & -0.29 & 0.9 & 0.96 & -1.35 & 1.53 & 0.95 \\
\hline & TN_OBS & -1.32 & 1.68 & 0.89 & -1.8 & 1.95 & 0.81 & -1.48 & 1.1 & 0.93 & -1.28 & 1.84 & 0.9 & -1.2 & 1.65 & 0.87 \\
\hline & E-OBS & -0.1 & 0.57 & 0.97 & -0.69 & 0.97 & 0.94 & 0.04 & 0.6 & 0.98 & 0.58 & 1.1 & 0.95 & -0.4 & 0.63 & 0.97 \\
\hline ERA-I & TN_OBS & -0.82 & 1.43 & 0.89 & -0.6 & 1.22 & 0.79 & -0.83 & 1.5 & 0.88 & -1.3 & 1.86 & 0.82 & -0.8 & 1.38 & 0.85 \\
\hline
\end{tabular}

Table 1: Annual and seasonal $\mathrm{T}_{\mathrm{avg}}$ errors. 
Citation: Fathalli B, Pohl B, Castel T, Safi MJ (2016) Dynamical downscaling of temperature variability over Tunisia: evaluation a 21-year-long simulation performed with the WRF model. J Climatol Weather Forecasting 4: 166. doi:10.4172/2332-2594.1000166

Page 4 of 8

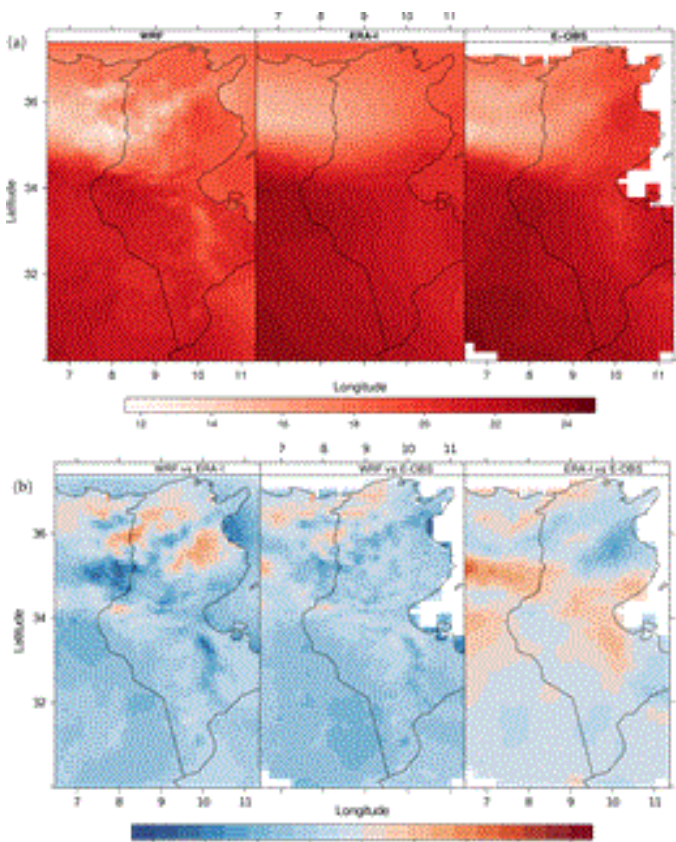

Figure 2: (a) Annual mean $\mathrm{T}_{\text {avg }}\left({ }^{\circ} \mathrm{C}\right)$ according to WRF, ERA-I and E-OBS and over the period 1992-2011. (b) Annual mean WRF $\mathrm{T}_{\text {avg }}$ biases $\left({ }^{\circ} \mathrm{C}\right.$ ) against ERA-I (left-hand column) and E-OBS (middle column), annual mean ERA-I biases $\left({ }^{\circ} \mathrm{C}\right)$ against E-OBS (righthand column).

Seasonal WRF biases (Figure 4) reveal a moderate seasonal dependency. From one season to another, the spatial distribution of the biases remains roughly similar, the main differences concerning the magnitude of the errors. This magnitude itself depends on seasons, particularly for JJA when the hot biases north of Tunisia are strongest. ERA-I, compared to E-OBS, largely overestimates JJA temperature (hot bias reaching $4^{\circ} \mathrm{C}$ ) in the center and south of Tunisia. Seasonal errors are listed in Table 1, showing that the largest WRF errors occur in DJF. The model is however closer to ERA-I then to the observational datasets in DJF (the lowest/highest spatial correlations/RMSE against observation are indeed obtained in winter).

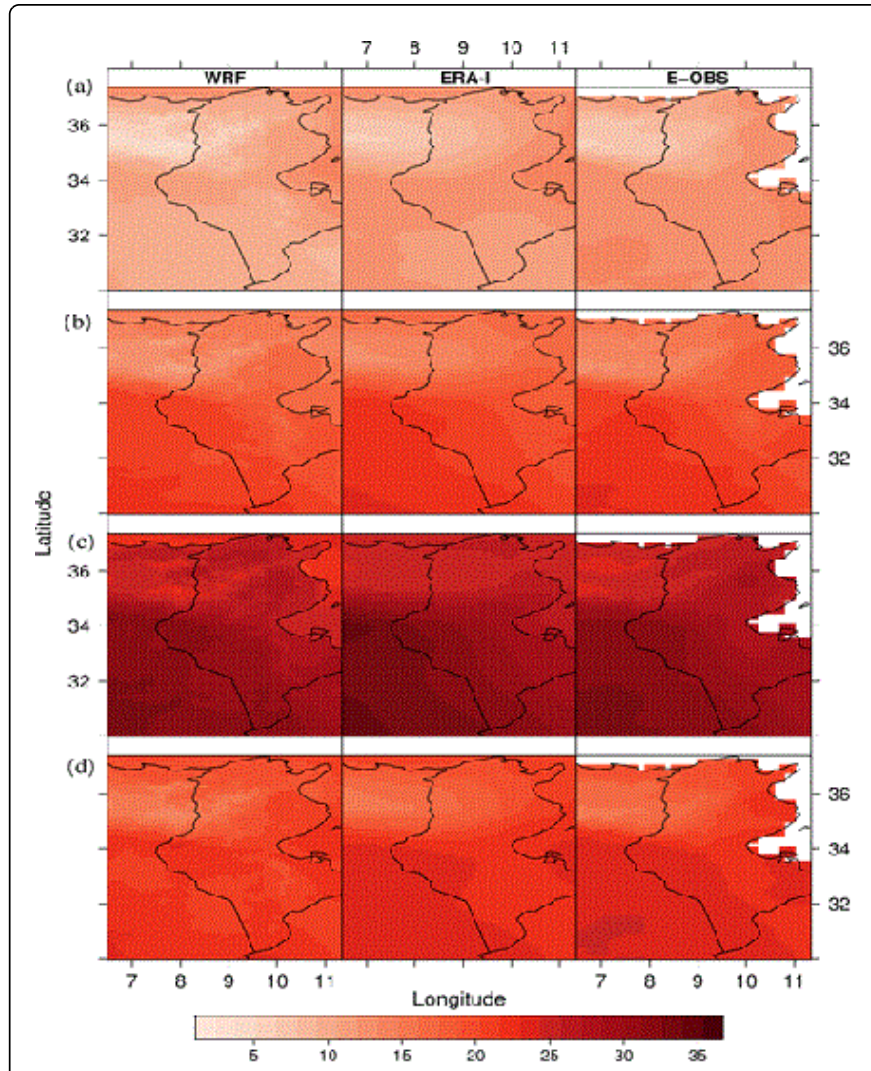

Figure 3: Seasonal mean $\mathrm{T}_{\text {avg }}\left({ }^{\circ} \mathrm{C}\right)$ according to WRF, ERA-I and EOBS, for DJF (a), MAM (b), JJA (c) and SON (d).

Contrary results are obtained in JJA when WRF is, on the one hand, much closer to observation $\left(\mathrm{R}=0.96\right.$ and $\mathrm{RMSE}=0.9^{\circ} \mathrm{C}$ with regard to E-OBS) and slightly outperforms its driving model, on the other hand. This WRF seasonal behavior can be explained by the synoptic patterns. In DJF large scale forcing is indeed prevailing (intense prevailing westerlies), temperature is then constrained by large scale forcing (ERA-I). The connection between wintertime Tunisian climate and large-scale patterns is particularly verified for observed precipitation [27]. Contrariwise, the synoptic forcing is weak in summer, anticyclonic conditions are in fact predominant over the Mediterranean Basin [28] and the model then could be more responding to strong local (small-scale) forcings and thus better capturing details of the regional climate.

\begin{tabular}{|c|c|c|c|c|c|c|c|c|c|c|c|c|c|c|c|c|}
\hline \multirow{2}{*}{$\begin{array}{l}\text { Model } \\
\text { WRF }\end{array}$} & \multirow[t]{2}{*}{ Ref } & \multicolumn{3}{|c|}{ Annual } & \multicolumn{3}{|l|}{ DJF } & \multicolumn{3}{|l|}{ MAM } & \multicolumn{3}{|l|}{ JJA } & \multicolumn{3}{|l|}{ SON } \\
\hline & & $\begin{array}{l}\mathrm{ME} \\
\left({ }^{\circ} \mathrm{C}\right)\end{array}$ & $\begin{array}{l}\text { RMSE } \\
\left({ }^{\circ} \mathrm{C}\right)\end{array}$ & $\mathrm{R}$ & $\begin{array}{l}\mathrm{ME} \\
\left({ }^{\circ} \mathrm{C}\right)\end{array}$ & $\begin{array}{l}\text { RMSE } \\
\left({ }^{\circ} \mathrm{C}\right)\end{array}$ & $\mathrm{R}$ & $\begin{array}{l}\mathrm{ME} \\
\left({ }^{\circ} \mathrm{C}\right)\end{array}$ & $\begin{array}{l}\text { RMSE } \\
\left({ }^{\circ} \mathrm{C}\right)\end{array}$ & $\mathrm{R}$ & $\begin{array}{l}\mathrm{ME} \\
\left({ }^{\circ} \mathrm{C}\right)\end{array}$ & $\begin{array}{l}\text { RMSE } \\
\left({ }^{\circ} \mathrm{C}\right)\end{array}$ & $\mathrm{R}$ & $\begin{array}{l}\mathrm{ME} \\
\left({ }^{\circ} \mathrm{C}\right)\end{array}$ & $\begin{array}{l}\text { RMSE } \\
\left({ }^{\circ} \mathrm{C}\right)\end{array}$ & $\mathrm{R}$ \\
\hline & ERA-I & -0.97 & 1.53 & 0.88 & -0.88 & 1.39 & 0.8 & -0.82 & 1.17 & 0.95 & -1.08 & 1.9 & 0.9 & -1.24 & 1.93 & 0.79 \\
\hline & E-OBS & -0.54 & 1.01 & 0.91 & -0.92 & 1.45 & 0.77 & -0.46 & 0.82 & 0.97 & -0.18 & 1.17 & 0.9 & -0.73 & 1.45 & 0.83 \\
\hline ERA-I & E-OBS & 0.43 & 0.83 & 0.95 & -0.04 & 0.78 & 0.89 & 0.36 & 0.74 & 0.97 & 0.9 & 1.41 & 0.95 & 0.51 & 0.89 & 0.95 \\
\hline
\end{tabular}

Table 2: Annual and seasonal $\mathrm{T}_{\min }$ errors. 
Citation: Fathalli B, Pohl B, Castel T, Safi MJ (2016) Dynamical downscaling of temperature variability over Tunisia: evaluation a 21-year-long simulation performed with the WRF model. J Climatol Weather Forecasting 4: 166. doi:10.4172/2332-2594.1000166

Page 5 of 8

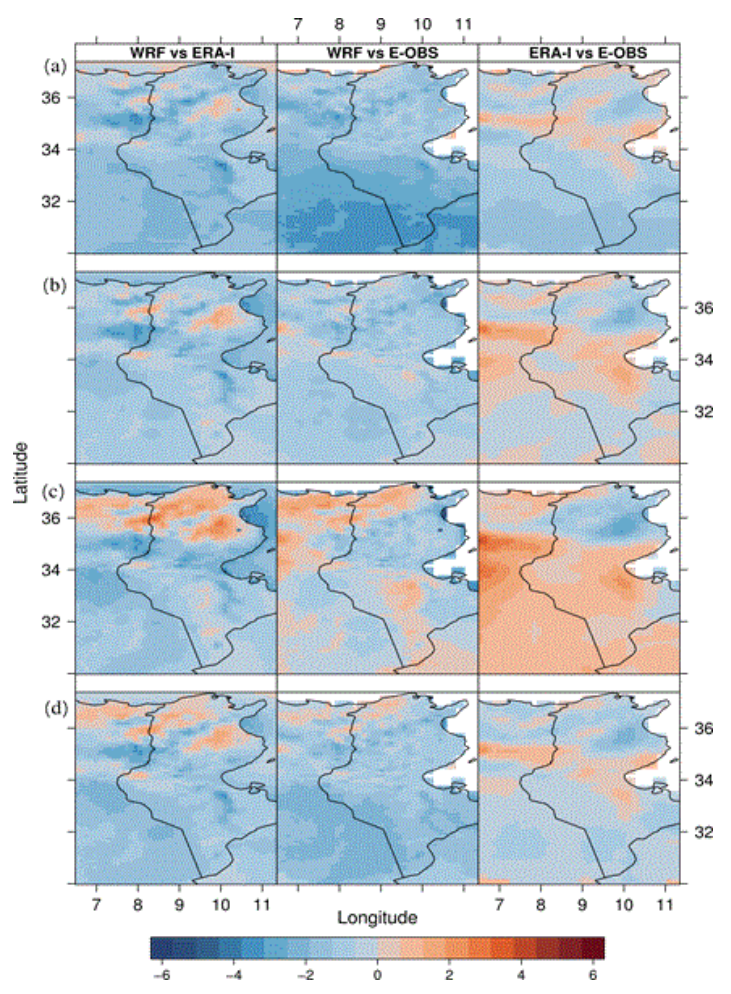

Figure 4: Seasonal mean WRF $\mathrm{T}_{\text {avg }}$ biases $\left({ }^{\circ} \mathrm{C}\right)$ against ERA-I (lefthand column) and E-OBS (middle column), seasonal mean ERA-I biases $\left({ }^{\circ} \mathrm{C}\right.$ ) against E-OBS (right-hand column), for DJF (a), MAM (b), JJA (c) and SON (d).

\section{Daily maximum and minimum temperatures}

Annual and seasonal spatial patterns of simulated, analyzed and observed 20-years average $\mathrm{T}_{\min }$ and $\mathrm{T}_{\max }$ (not shown) over landmasses are in agreement with the broad altitudinal pattern of the Tunisian mean temperatures.

A seasonal sea-land thermal contrast can however be noticed for both $\mathrm{T}_{\min }$ and $\mathrm{T}_{\max }$. Indeed, $\mathrm{T}_{\min }$ (ranging in WRF from $\sim 1^{\circ} \mathrm{C}$ to $\sim 26^{\circ} \mathrm{C}$ ) is higher over the sea (particularly over the Gulf of Gabeseast of Tunisia) then over landmasses in all seasons, excepting in JJA when the maximum occurs in the Chotts depression.

The opposite pattern is observed for $\mathrm{T}_{\max }$ (ranging in WRF from $\sim 7^{\circ} \mathrm{C}$ to $\sim 41^{\circ} \mathrm{C}$ ) being lower over the sea in all seasons, excepting in DJF when the minimum occurs along the Tunisian Dorsale. Annual correlation coefficients between $\mathrm{WRF}$ and the comparing datasets (listed in Tables 2 and 3) are higher for $\mathrm{T}_{\max }$ than for $\mathrm{T}_{\min }$. Similar findings are reported by other authors who used WRF to downscale temperature over Portugal [9] and over the US North pacific [29].

Spatial patterns of seasonal WRF and ERA-I $\mathrm{T}_{\min }$ and $\mathrm{T}_{\max }$ mean biases with regard to E-OBS are respectively shown in Figures 5 and 6. These patterns are broadly consistent with those of $\mathrm{T}_{\text {avg }}$ previously described.

The largest ERA-I errors concern $\mathrm{T}_{\min }$ and are occurring in summer. WRF particularly underestimates $\mathrm{T}_{\max }$ in DJF when the cold biases are prevalent and can locally exceed $-10^{\circ} \mathrm{C}$. Seasonal errors (listed in Tables 2 and 3) show indeed that the largest WRF errors are obtained in DJF and mostly concern $\mathrm{T}_{\max }\left(\mathrm{RMSE} \sim 2.6^{\circ} \mathrm{C}\right)$. WRF $\mathrm{T}_{\min }$ shows a slight improvement on ERA-I only in summer. However, ERAI always performs better than WRF (particularly in DJF and less in JJA) when reproducing the $T_{\max }$ spatial variability.

\begin{tabular}{|c|c|c|c|c|c|c|c|c|c|c|c|c|c|c|c|c|}
\hline \multirow[t]{2}{*}{ Model } & \multirow[t]{2}{*}{ Ref } & \multicolumn{3}{|c|}{ Annual } & \multicolumn{3}{|l|}{ DJF } & \multicolumn{3}{|l|}{ MAM } & \multicolumn{3}{|l|}{ JJA } & \multicolumn{3}{|l|}{ SON } \\
\hline & & $\begin{array}{l}\mathrm{ME} \\
\left({ }^{\circ} \mathrm{C}\right)\end{array}$ & $\begin{array}{l}\text { RMSE } \\
\left({ }^{\circ} \mathrm{C}\right)\end{array}$ & $\mathrm{R}$ & $\begin{array}{l}\mathrm{ME} \\
\left({ }^{\circ} \mathrm{C}\right)\end{array}$ & $\begin{array}{l}\text { RMSE } \\
\left({ }^{\circ} \mathrm{C}\right)\end{array}$ & $\mathrm{R}$ & $\begin{array}{l}\mathrm{ME} \\
\left({ }^{\circ} \mathrm{C}\right)\end{array}$ & $\begin{array}{l}\text { RMSE } \\
\left({ }^{\circ} \mathrm{C}\right)\end{array}$ & $\mathrm{R}$ & $\begin{array}{l}\mathrm{ME} \\
\left({ }^{\circ} \mathrm{C}\right)\end{array}$ & $\begin{array}{l}\text { RMSE } \\
\left({ }^{\circ} \mathrm{C}\right)\end{array}$ & $\mathrm{R}$ & $\begin{array}{l}\mathrm{ME} \\
\left({ }^{\circ} \mathrm{C}\right)\end{array}$ & $\begin{array}{l}\text { RMSE } \\
\left({ }^{\circ} \mathrm{C}\right)\end{array}$ & $\mathrm{R}$ \\
\hline \multirow[t]{2}{*}{ WRF } & ERA-I & -1.5 & 1.86 & 0.95 & -1.92 & 2.15 & 0.89 & -1.86 & 1.94 & 0.96 & -1.2 & 1.87 & 0.92 & -1.25 & 1.63 & 0.94 \\
\hline & $\mathrm{E}-\mathrm{OBS}$ & -1.54 & 1.77 & 0.95 & -2.47 & 2.57 & 0.94 & -1.56 & 1.84 & 0.96 & -0.81 & 1.59 & 0.92 & -1.56 & 1.73 & 0.96 \\
\hline ERA-I & E-OBS & -0.04 & 0.96 & 0.95 & -0.56 & 0.79 & 0.97 & 0.3 & 1.12 & 0.96 & 0.32 & 1.54 & 0.92 & -0.31 & 0.91 & 0.96 \\
\hline
\end{tabular}

Table 3: Annual and seasonal $\mathrm{T}_{\max }$ errors. 
Citation: Fathalli B, Pohl B, Castel T, Safi MJ (2016) Dynamical downscaling of temperature variability over Tunisia: evaluation a 21-year-long simulation performed with the WRF model. J Climatol Weather Forecasting 4: 166. doi:10.4172/2332-2594.1000166

Page 6 of 8

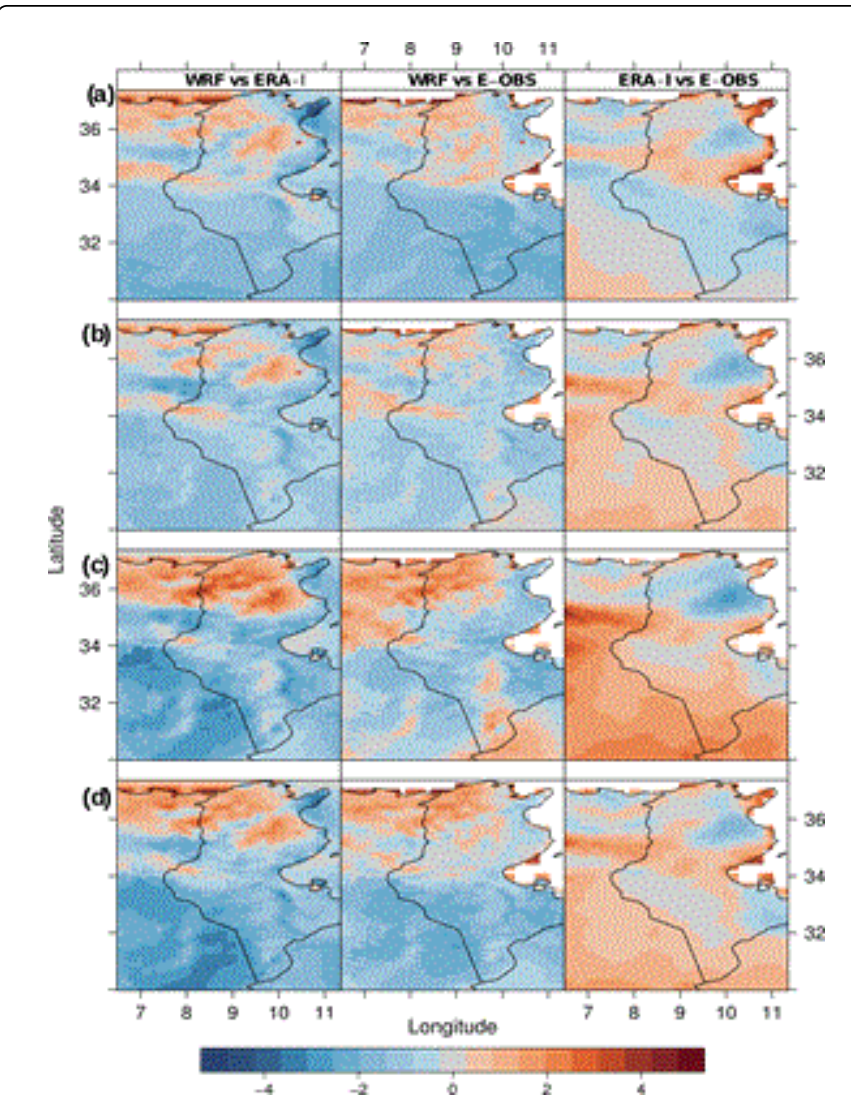

Figure 5: As (4) but for $\mathrm{T}_{\min }$.

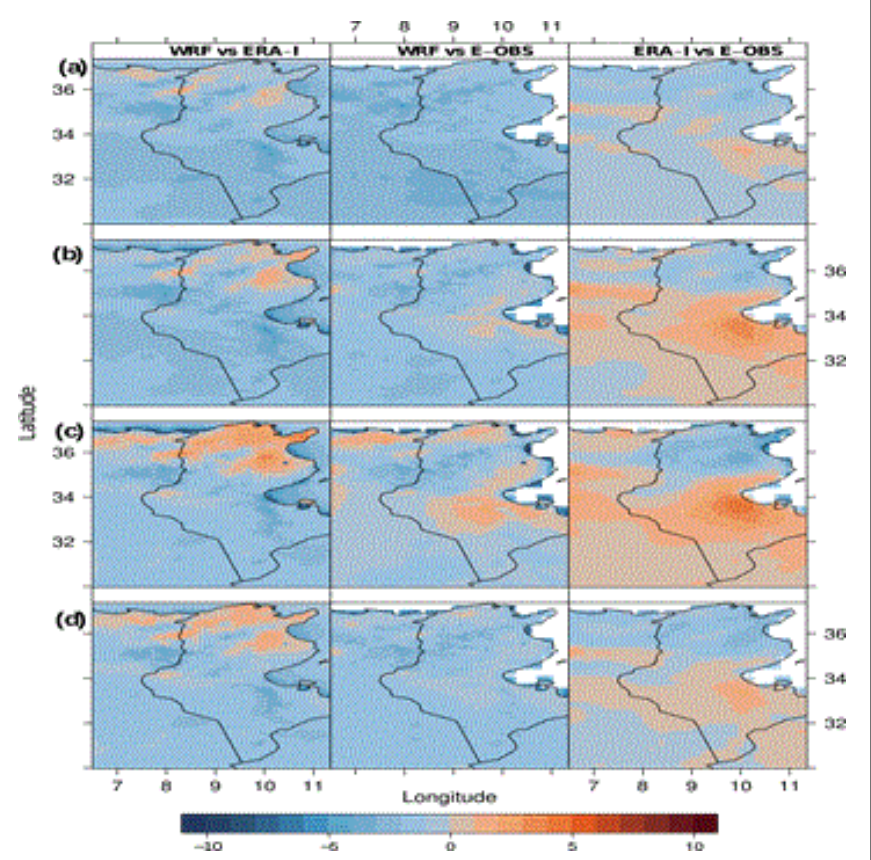

Figure 6: As (4) but for $\mathrm{T}_{\max }$.

\section{Temporal variability}

Figure 7a shows the interannual variability of WRF, ERA-I and EOBS $\mathrm{T}_{\text {avg }}$ spatially averaged over the landmass grid-points of the domain. A good agreement between ERA-I and E-OBS is noteworthy supporting the relevance of this reanalysis product. Concerning WRF errors, in spite of a systematic cold bias prevailing throughout the whole simulation period (reaching a maximum of $-1.36^{\circ} \mathrm{C}$ against $\mathrm{E}$ OBS), the year-to-year variations of $\mathrm{T}_{\mathrm{avg}}$ is well reproduced by the model. Interannual correlation coefficients are indeed very high against ERA-I $(\mathrm{R}=0.95)$ and E-OBS $(\mathrm{R}=0.93)$.

Compared to the Tunisian stations (Figure $7 \mathrm{~b}$ ), all gridded datasets underestimate temperature. The maximum bias is recorded in WRF and ranges from -1 to $-1.7^{\circ} \mathrm{C}$.
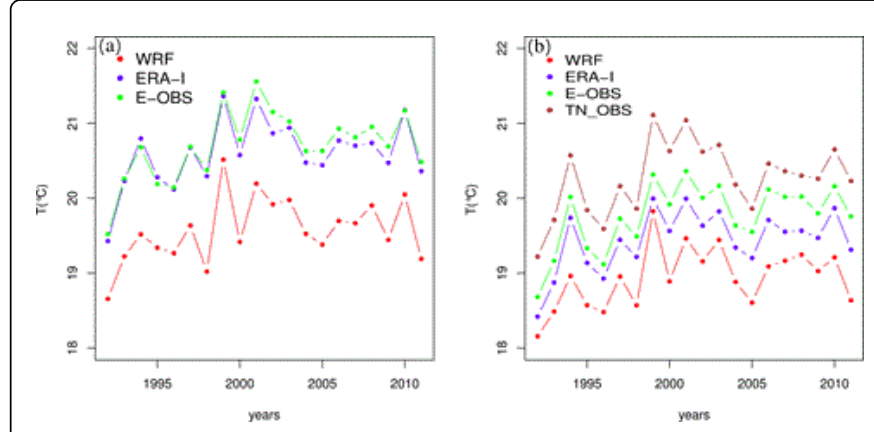

Figure 7: (a) Interannual variability of $\mathrm{T}_{\text {avg }}\left({ }^{\circ} \mathrm{C}\right)$ spatially averaged over the landmass grid-points of the domain, and according to WRF, ERA-I and E-OBS. (b) As (a) but for the Tunisian weather stations (TN_OBS) and the nearest grid-points of WRF, ERA-I and E-OBS.

Long-term mean annual cycles of $\mathrm{T}_{\mathrm{avg}}$ in $\mathrm{WRF}$ and the comparing datasets are plotted in Figure $8 \mathrm{a}$ for the landmasses of the whole domain and in Figure $8 \mathrm{~b}$ for TN_OBS and the nearest grid points of gridded datasets to the local weather stations.

The strong seasonality of the Tunisian temperature and its unimodal distribution are well captured by the model. The minimum and maximum simulated $\mathrm{T}_{\text {avg }}$ are respectively recorded in January $\left(\sim 9^{\circ} \mathrm{C}\right)$ and August $\left(\sim 30^{\circ} \mathrm{C}\right)$ and are in quite agreement with the other datasets. However, WRF underestimates spatially averaged $\mathrm{T}_{\mathrm{avg}}$ throughout the whole annual cycle but mainly in winter.

In fact, WRF shows a quite strong cold bias with respect to E-OBS in DJF (especially in January when the cold bias exceeds $-2^{\circ} \mathrm{C}$ ) unlike summer when the model is notably close to E-OBS so the cold bias barely exceeds $-0.2^{\circ} \mathrm{C}$. Compared to TN_OBS, WRF also shows a systematic cold bias ranging from $-1.8^{\circ} \mathrm{C}$ in February to $-0.8^{\circ} \mathrm{C}$ in September. 

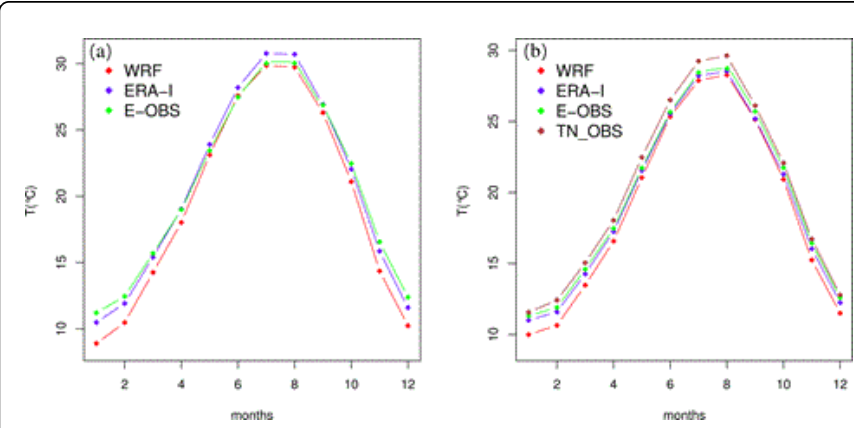

Figure 8: (a) $\mathrm{T}_{\text {avg }}\left({ }^{\circ} \mathrm{C}\right)$ mean annual cycle spatially averaged over the landmass grid-points of the domain, and according to WRF, ERA-I and E-OBS. (b) As (a) but for the Tunisian weather stations (TN_OBS) and the nearest grid-points of WRF, ERA-I and E-OBS.

Interannual variabilities of the spatially averaged $\mathrm{T}_{\min }$ and $\mathrm{T}_{\max }$ are shown in Figures 9a and 9b. WRF systematically underestimates both $\mathrm{T}_{\min }$ and $\mathrm{T}_{\max }$ throughout the whole simulation period. Nevertheless, the largest errors concern $\mathrm{T}_{\max }$, thereby ranging from $-1.9^{\circ} \mathrm{C}$ to $-1^{\circ} \mathrm{C}$ with respect to E-OBS. ERA-I systematically overestimates $\mathrm{T}_{\min }$ unlike $\mathrm{T}_{\max }$ being in perfect agreement with the observation $(\mathrm{R}=0.98)$.

Mean annual cycles of $\mathrm{T}_{\min }$ and $\mathrm{T}_{\max }$ are plotted in Figures 10a and 10b. Consistently with our previous findings, the main WRF errors concern $\mathrm{T}_{\max }$ and occur in wintertime, particularly in January when the systematic cold bias against E-OBS reaches its maximum $\left(\sim-3^{\circ} \mathrm{C}\right)$.

The model $\mathrm{T}_{\min }$ is slightly underestimated against E-OBS except in June when WRF marginally overestimates temperature (bias $\sim 0.2^{\circ} \mathrm{C}$ ). Furthermore, WRF $\mathrm{T}_{\text {min }}$ is rather in better agreement with E-OBS in JJA pointing out again the important role of regional small-scale processes being resolved by the regional model in summer. Contrariwise, the main ERA-I errors concern $\mathrm{T}_{\text {min }}$ being overestimated in summer (a hot bias reaching $\sim 1^{\circ} \mathrm{C}$ in August).
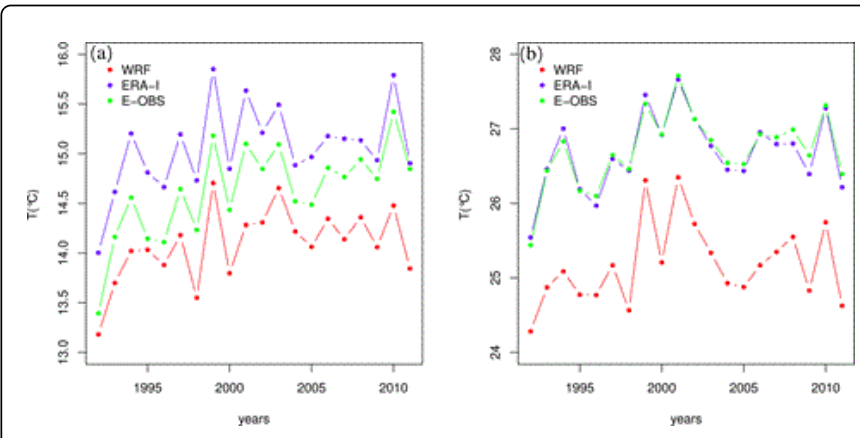

Figure 9: (a) As (7a) but for $\mathrm{T}_{\min }$. (b) As (7a) but for $\mathrm{T}_{\max }$.
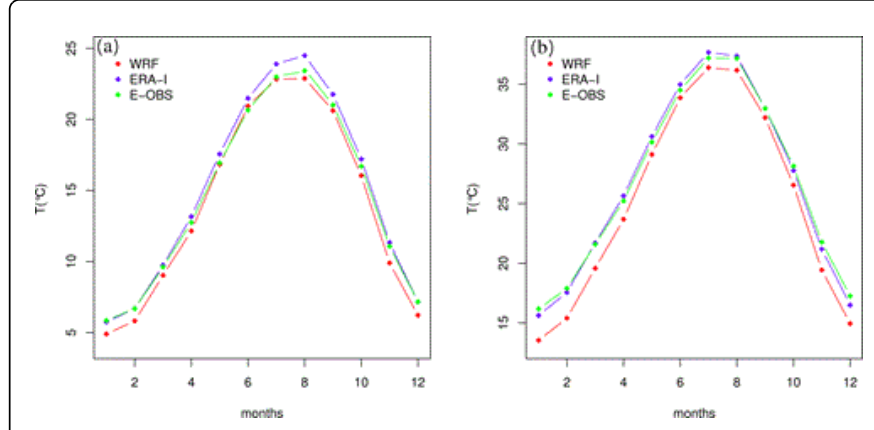

Figure 10: (a) As (8a) but for $\mathrm{T}_{\min }$. (b) As (8a) but for $\mathrm{T}_{\max }$.

Our results may suggest that the WRF errors are not inherited from its driving model but are rather internal to the model itself. Indeed, underestimation of the daily average temperature seems to be a consequence of systematic underestimation of $\mathrm{T}_{\max }$ (mainly in winter) and less of $\mathrm{T}_{\mathrm{min}}$, which is not verified in ERA-I. Underestimation of temperature then could be linked to deficiencies in the model parameterizations of diurnal/nocturnal physics that particularly control $\mathrm{T}_{\max } / \mathrm{T}_{\min }$ [29]. The surface radiation budget (latent and heat fluxes at the surface), the PBL physics as well as the downward/ outgoing shortwave / longwave radiations at the top of the atmosphere are physical processes that strongly impact $\mathrm{T}_{\max } / \mathrm{T}_{\min }$. Evaluating the capability of WRF in simulating these processes is beyond the scope of this study.

\section{Conclusion}

The present study contributes for the first time to the evaluation of a near-surface air temperature simulation over Tunisia at $12 \mathrm{~km}$ spatial resolution. A current state-of-the-art non-hydrostatic regional (WRF) model driven by the most recent ECMWF climate reanalysis (ERAInterim) has been used to downscale temperature spatial and temporal variabilities over a 21-year long period (1991-2011). Analyses of the simulation are carried out at the annual and seasonal timescales and the WRF skills in simulating daily average $\left(\mathrm{T}_{\mathrm{avg}}\right)$, maximum $\left(\mathrm{T}_{\max }\right)$ and minimum $\left(\mathrm{T}_{\min }\right)$ temperatures are assessed against gridded climatological datasets (ERA-I and E-OBS) and against high-quality in-situ data from 18 Tunisian weather stations. Overall, the model proves good performances in reproducing the spatial variability of mean annual and seasonal temperatures showing significant topographic signatures. Indeed, WRF correctly captures the minimum temperatures always recorded along the main Tunisian mountain ranges (particularly the Tunisian Dorsale), as well as the maximum mainly occurring in the salt chott depressions. Temporal variability of temperature is satisfactorily reproduced by WRF, despite cold biases obtained for $\mathrm{T}_{\text {avg }}, \mathrm{T}_{\min }$ and $\mathrm{T}_{\max }$, and systematically reproduced throughout the whole simulation period or the mean annual cycle. WRF tends indeed to underestimate temperature especially in DJF when the strongest cold biases are obtained and are mostly linked to an underestimation of $\mathrm{T}_{\max }$. Results also show that the model skills depend on seasons. In fact, WRF is closer to its driving model in winter then to observation, unlike summer when WRF is notably in good agreement with E-OBS and it exclusively (but slightly) outperforms ERA-I when simulating $\mathrm{T}_{\mathrm{avg}}$ and $\mathrm{T}_{\min }$. This model seasonal behaviour could be linked to the Mediterranean (generally the mid-latitudes) large-scale atmospheric patterns. In winter, the synoptic forcing is active (intense westerlies) and the model then could be 
constrained by the ERA-I forcing. Contrariwise in summer, the low synoptic forcing could enhance the model freedom in developing its own climate thus allowing it to better capture details of the regional climate. ERA-I errors are quite different from WRF since they mainly concern $\mathrm{T}_{\text {min }}$ being overestimated in JJA, then suggesting that the WRF errors are not inherited from its driving model but could rather be linked to deficiencies in the regional model, especially in the model parameterizations of physical processes (surface radiation budget, PBL physics and downward/outgoing shortwave / longwave radiations at the top of the atmosphere) that have a large impact on daytime / nighttime temperatures. A further study focusing on evaluating the capabilities of WRF in simulating these physical processes and also investigating other physical options seems to be worthy in order to better understand the origin of the WRF errors. Finally, this study presents a high-quality climatological dataset which can be used as reference for climate impact studies.

\section{Acknowledgments}

We wish to thank anonymous reviewers for their constructive comments that helped improve the paper. WRF was provided by the University Corporation for Atmospheric Research website (for more information see http://www.mmm.ucar.edu/wrf/users/download/). ERA-Interim data were provided by the ECMWF. Calculations were performed using HPC resources from DSI-CCUB, université de Bourgogne. We acknowledge the E-OBS dataset from the EU-FP6 project ENSEMBLES (http://ensembles-eu.metoffice.com), and the data providers in the ECA\&D project (http://www.ecad.eu) and the NCDC (http://www.ncdc.noaa.gov/) for making available the Tunisian weather station data.

\section{References}

1. Giorgi F, Jones C, Asrar GR (2009) Addressing climate information needs at the regional level: the CORDEX framework. WMO Bull 5: 175-183.

2. IPCC (2007) Climate Change 2007, the Fourth Assessment Report AR4 of the United Nations Intergovernmental Panel on Climate Change IPCC, Working Group I, The Physical Science Basis of Climate Change.

3. Chen J, Brissette FP, Leconte R (2012) Coupling statistical and dynamical methods for spatial downscaling of precipitation. Clim Change 114: 509-526.

4. Brown C, Greene AM, Block PJ, Giannini A (2008) Review of downscaling methodologies for Africa climate applications. IRI Technical Report 08-05.

5. Hay LE, Clark MP (2003) Use of statistically and dynamically downscaled atmospheric model output for hydrologic simulations in three mountainous basins in the western United States. J Hydrol 282: 56-75.

6. Fowler HJ, Blenkinshop S, Tebaldi C (2007) Linking climate change modelling to impacts studies: recent advances in downscaling techniques for hydrological modeling. Int J Climatol 27: 1547-1578.

7. Teutschbein C, Wetterhall F, Seibert J (2011) Evaluation of different downscaling techniques for hydrological climate-change impact studies at the catchment scale. ClimDyn 37: 2087-2105.

8. Caldwell P, Chin HNS, Bader DC, Bala G (2009) Evaluation of a WRF dynamical downscaling simulation over California. Clim. Change 95: 499-521.

9. Soares PMM, Cardoso RM, Miranda PMA, de Medeiros J, Belo- Pereira $\mathrm{M}$, et al. (2012) WRF high resolution dynamical downscaling of ERAInterim for Portugal. ClimDyn 39: 2497-2522.
10. Heikkilä U, Sandvick A, Sorteberg A (2010) Dynamical downscaling of ERA-40 in complex terrain using the WRF regional climate model. ClimDyn 37: 1551-1564.

11. Gonçalves M, Barrera-Escoda A, Guerreiro D, Baldasano JM, Cunillera J (2014) Seasonal to yearly assessment of temperature and precipitation trends in the North Western Mediterranean Basin by dynamical downscaling of climate scenarios at high resolution (1971-2050) Climatic Change 122: 243-256.

12. Flaounas E, Drobinski F, Vrac M, Bastin S, Lebeaupin-Brossier C et al (2013) Precipitation and temperature space-time variability and extremes in the Mediterranean region: evaluation of dynamical and statistical downscaling methods. ClimDyn 40: 2687-2705.

13. Verner D (2013) Tunisia in a Changing Climate : Assessment and Actions for Increased Resilience and Development.

14. Gao L, Bernhardt M, Schulz K (2012) Elevation correction of ERAInterim temperature data in complex terrain. Hydrol Earth Syst Sci 16: 4661-4673.

15. Dee DP, Uppala SM, Simmons AJ, Berrisford P, Poli P, et al. (2011) The ERA-Interim reanalysis: configuration and performance of the data assimilation system. Q J R Meteorol Soc. 137: 553-597.

16. Haylock MR, Hofstra N, Klein Tank AMG, Klok EJ, Jones PD, et al. (2008) A European daily high resolution gridded data set of surface temperature and precipitation for 1950-2006. J Geophys Res 113: 119.

17. van den Besselaar EJM, Haylock MR, van der Schrier G, Klein Tank AMG (2011) A European daily high-resolution observational gridded data set of sea level pressure. J Geophys Res 116: 1-11.

18. Skamarock WC, Klemp JB, Dudhia J, Gill DO, Barker DM, et al. (2008) A Description of the Advanced Research WRF Version 3.125.

19. Hong SY, Lim JOJ (2006) The WRF single-moment 6-class microphysics scheme (WSM6). J Kor MeteorolSoc 42: 129-151.

20. Hong SY, Noh Y, Dudhia J (2006) A new vertical diffusion package with an explicit treatment of entrainment processes. Mon Weather Rev 134: 2318-2341.

21. Paulson CA (1970) The mathematical representation of wind speed and temperature profiles in the unstable atmospheric surface layer. J Appl Meteor 9: 857-861.

22. Mlawer E, Taubman S, Brown P, Iacono M, Clough S (1997) Radiative transfer for inhomogeneous atmosphere: RRTM, a validated correlated- $\mathrm{k}$ model for the long-wave. J Geophys Res 102: 16663-16682.

23. Dudhia J (1989) Numerical study of convection observed during the winter monsoon experiment using a mesoscale two-dimensional model. J AtmosSci 46: 3077-3107.

24. Kain JS (2004) The Kain-Fritsch convective parameterization: an update. J ApplMeteorol 43: 170-181.

25. Chen F, Dudhia J (2001) Coupling an advanced land-surface/hydrology model with the Penn State/NCAR MM5 modeling system. Part II: Preliminary model validation. Mon Weather Rev 129: 587-604.

26. Friedl MA, McIver DK, Hodges JCF, Zhang XY, Muchoney D, et al. (2002) Global land cover mapping from MODIS: algorithms and early results. Remote Sens Environ 83: 287-302.

27. Ouachani R, Bargaoui Z, Ouarda T (2013) Power of teleconnection patterns on precipitation and streamflow variability of upper Medjerda Basin. Int J Climtol 33: 58-76.

28. Elizalde A (2011) The water cycle in the Mediterranean region and the impacts of climate change. Max Planck Institute for Meteorology Rep on Earth System Science 103: p 128.

29. Zhang Y, Dulière V, Mote P, Salathé EP (2009) Evaluation of WRFand HadRM mesoscale climate simulations over the UnitedStates Pacific Northwest. J Clim 22: 5511-5526. 